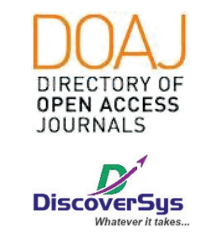

Published by DiscoverSys

\section{Study of knowledge in diarrhea and personal hygiene among students below 10 years old in SD Santo Yoseph 2, Denpasar in 2016-2017}

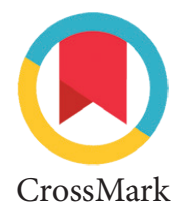

Karthigeyan Manogaran, ${ }^{1 *}$ I Made Gede Dwi Lingga Utama, ${ }^{2}$ I Wayan Gustawan²
Background: The lack of basic knowledge of diarrhea and also poor self-hygiene might be the risk factors of diarrhea.

Aim: The study aims to identify the knowledge of diarrhea and personal hygiene among student below 10 years old in SD Santo Yoseph 2, Denpasar, Bali.

Method: This cross sectional study was conducted on students below 10 years old in SD Santo Yoseph 2, Denpasar. Fifty students participated in this study, and they were divided into two groups. Of total study participants, 25 were from 8 years old, and 25 were from 9 years old. They were asked to fill up a self-administered questionnaire. The variables assessed were their knowledge of diarrhea (definition, etiology, risk factors, sign and symptoms, complications, treatment and management, and prevention) and application of personal hygiene.
Result: About 34\% of 50 students below 10 years old in SD Santo Yoseph respectively had good knowledge of diarrhea. However, $66 \%$ of students had very less knowledge about diarrhea where they get below. For the application of personal hygiene, 24\% of students managed to get a good score while $74 \%$ of them failed to get a good score. The vast majority had adequate knowledge of the definition of diarrhea. At the same time, the majority of the students was unable to know that dehydration is the complication of diarrhea due to the loss of a large amount of water and salt in the body.

Conclusion: Though the overall knowledge in diarrhea and application of hygienic lifestyle among the students were poor, few minorities of the students had a good understanding of both these variables. There is a strong need for early childhood education about knowledge in diarrhea and personal hygiene in school level itself as a method of prevention.

Keywords: Diarrhea, level of knowledge, personal hygiene

Cite This Article: Manogaran, K., Utama, I.M.G.D.L., Gustawan, I.W. 2019. Study of knowledge in diarrhea and personal hygiene among students below 10 years old in SD Santo Yoseph 2, Denpasar in 2016-2017. Intisari Sains Medis 10(2): 363-367. D0I: 10.15562/ism.v10i2.411

${ }^{1}$ Medical Profession and Undergraduate Program, Medical Faculty, Udayana University

${ }^{2}$ Department of Pediatric Health Science, Medical Faculty, Udayana University, Sanglah General Hospital Denpasar Bali

${ }^{*}$ Correspondence to: Karthigeyan Manogaran, Medical Profession and Undergraduate Program, Medical Faculty, Udayana University

bulletkarthi10@gmail.com

Received: 2019-02-07

Accepted: 2019-04-16

Published: 2019-08-01

\section{INTRODUCTION}

Diarrhea is generally defined as the passage of three or more unformed stools per day, often in addition to other enteric symptoms, or the passage of more than $250 \mathrm{~g}$ of unformed stool per day. By its duration, diarrhea can be classified as acute ( $<14$ days), persistent (14 to 29 days), or chronic ( $\geq 30$ days). Gastroenteritis, which is often due to viral infection involving the stomach and small intestine, is associated with vomiting and diarrhea. Based on the Bali Provincial Health Profile of the Year 2014, there was an increase in diarrhea cases from the year 2013 which was 86.4 to 87.845 in the year 2014 .

The idea of this study is based on research conducted in Kota Manado in the year 2014 with the objective to analyze the relationship between hand-washing behavior towards the incidence of diarrhea in children of SD Advent Sario Kota Manado. ${ }^{1}$ Researcher manages to prove that there is a correlation between hand-washing and prevalence of diarrhea among the students because 29\% of the students who don't wash hand properly had diarrhea. At the end of the research, few students cleaned hand properly yet they had diarrhea.
Therefore the risk factors are unknown. Thus, the lack of basic knowledge of diarrhea and also poor self-hygiene might be the risk factors of diarrhea in that case. So far there were no studies conducted in Bali regarding diarrhea among primary school children, especially in Denpasar which is the capital of Bali.

\section{METHOD}

This study is a descriptively approached cross-sectional design to determine the knowledge in diarrhea and personal hygiene among students below 10 years old in SD Santo Yoseph 2, Denpasar, using questionnaires as the study tool from 2016 until 2017. They were divided into two particular groups, eight years old and also 9. As for a stratified method, the estimated sample sizes were 49 students from 8 years old and 51 students from 9 years old. Once stratified method committed, consecutive method went on.

Questionnaires were evenly distributed to both sets of students, 25 samples from 8 years old and another 25 samples from 9 years old. The overall knowledge in diarrhea and application of personal 
hygiene score of the participants was range from minimum score 0 to maximum score 2 . There were fourteen questions based on knowledge in diarrhea and also six questions based on the application of hygienic lifestyle.

\section{RESULT}

\section{Distribution of total score}

The group of 9 years old students has collected 450 points in the knowledge of diarrhea as against 318 points collected by the group of 8 . Besides, 118 points were collected by the students of 8 years old for the application of hygienic lifestyle which is still low as against 150 points obtained by the 9 . The bar chart in Figure 1 visualizes the difference in score obtained by both groups where the blue represents 8 years old, and the orange bar represents the 9 one.

\section{Frequency distribution of knowledge in diarrhea and personal hygiene}

Based on Table 1, about $34 \%$ of the 50 students had good knowledge in diarrhea where they managed to score more than $61 \%$ while the rest $66 \%$ of the

\begin{tabular}{|c|c|c|c|}
\hline \multicolumn{4}{|l|}{500} \\
\hline \multicolumn{4}{|l|}{400} \\
\hline \multicolumn{4}{|l|}{300} \\
\hline 200 & & & \\
\hline \multicolumn{4}{|l|}{100} \\
\hline \multicolumn{4}{|l|}{0} \\
\hline & Knowledge in diarrhea & \multicolumn{2}{|c|}{ Application of hygienic lifestyle } \\
\hline \multicolumn{4}{|c|}{$\square$ years old $\quad 9$ years old } \\
\hline Figure 1 & \multicolumn{3}{|c|}{$\begin{array}{l}\text { The bar chart shows the difference in score collected by both eight } \\
\text { and nine years old students }\end{array}$} \\
\hline Table 1 & \multicolumn{3}{|c|}{ Characteristic of samples } \\
\hline Variables & & $\mathbf{N}$ & $\%$ \\
\hline \multicolumn{4}{|c|}{ Age of students } \\
\hline 9 years & & 25 & 100 \\
\hline 8 years & & 25 & 100 \\
\hline \multicolumn{4}{|c|}{ Knowledge in diarrhea } \\
\hline $\operatorname{Good}(\geq$ & $\geq 61 \%)$ & 17 & 34 \\
\hline $\operatorname{Bad}(<6$ & $1 \%)$ & 33 & 66 \\
\hline \multicolumn{4}{|c|}{ Application of hygenic lifestyle } \\
\hline Good $(\geq$ & $\geq 58 \%)$ & 12 & 24 \\
\hline $\operatorname{Bad}(<5$ & $8 \%)$ & 38 & 76 \\
\hline
\end{tabular}

students had poor knowledge in diarrhea since they failed to score more $61 \%$. Meanwhile for the application of hygienic lifestyle, there were $24 \%$ of students who managed to get a good score where they score more than $58 \%$, while on the other hand there were $76 \%$ of students who had scored less than $58 \%$ which is claimed as a poor score in the application of hygienic lifestyle. In comparison, more students have scored in the knowledge of diarrhea compared to the implementation of hygienic lifestyle, even though the difference was only $10 \%$.

\section{Description of the level of knowledge in diarrhea}

The level of knowledge in diarrhea was tested based on a few basic questions about diarrhea which were prepared for the students to answer. The response was recorded in the form of "YES" and "NO", where the students will say YES if they agree with the statement given and they answer NO if they disagree with the comments or. The questions were divided into 7 division which comprises of definition, etiology, risk factors, sign and symptoms, complications, treatment and management and also prevention. $90 \%$ of the students understand the meaning of diarrhea which is an increase in stool frequency to twice or more watery stools per day. Only $26 \%$ of the students answered wrong when asked about the etiology where rotavirus and Escherichia coli are the two most common agent of diarrhea.

As for the risk factors, $48 \%$ of the student says that contaminated water can cause diarrhea, while $54 \%$ of the students think that food which is prepared and stored in unsanitary conditions is not a risk factor. Then, $48 \%$ agrees that diarrhea is common when there is a shortage of adequate sanitation and hygiene. About $84 \%$ of students know that people having diarrhea will experience loose or watery stools as one of the sign and symptoms.

On the other hand, $16 \%$ of the students disagree that will have abdominal cramps during diarrhea. $24 \%$ of them says that they will have a fever if diarrhea persists for more than one day. $90 \%$ of the students are not aware that the complication of diarrhea is dehydration due to loss of a large amount of water and salt. $74 \%$ says that they should drink plenty of water to avoid dehydration as one of the management for diarrhea. Only $38 \%$ of students agree to take oral rehydration solution (ORC) to control diarrhea. Then, $14 \%$ of them did not conformed to eat small, light meals and also avoid fatty or spicy foods during diarrhea. There were $42 \%$ decided to have very good self-hygiene by always make it as a habit to wash hands before and after doing something, as a method of prevention for diarrhea. Besides, $34 \%$ of them agreed to the statement to avoid food from street vendors. 
Table 2 Level of knowledge in diarrhea

\begin{tabular}{|c|c|c|}
\hline Questions & Yes (\%) & No (\%) \\
\hline A. Definition & $45(90 \%)$ & $5(10 \%)$ \\
\hline B. Etiology & $37(74 \%)$ & $13(26 \%)$ \\
\hline \multicolumn{3}{|l|}{ C. Risk Factors } \\
\hline 1. Contaminated water can cause diarrhea & $24(48 \%)$ & $26(52 \%)$ \\
\hline $\begin{array}{l}\text { 2. Food which is prepared and stored in unhygienic } \\
\text { conditions }\end{array}$ & $23(46 \%)$ & $27(54 \%)$ \\
\hline $\begin{array}{l}\text { 3. Diarrhea is common when there is a shortage of } \\
\text { adequate sanitation and hygiene }\end{array}$ & $24(48 \%)$ & $26(52 \%)$ \\
\hline \multicolumn{3}{|l|}{ D. Sign and Symptoms } \\
\hline 1. Will experience watery or loose stools & $42(84 \%)$ & $8(16 \%)$ \\
\hline 2. During diarrhea will have abdominal cramps & $42(84 \%)$ & $8(16 \%)$ \\
\hline 3. Will have a fever persists more than one day & $24(48 \%)$ & $26(52 \%)$ \\
\hline \multicolumn{3}{|l|}{ E. Complication } \\
\hline $\begin{array}{l}\text { 1. Causes dehydration due to loss of a large amount of } \\
\text { water and salt }\end{array}$ & $5(10 \%)$ & $45(90 \%)$ \\
\hline \multicolumn{3}{|l|}{ F. Treatment and Management } \\
\hline 1. Should drink plenty of water to avoid dehydration & $37(74 \%)$ & $13(46 \%)$ \\
\hline $\begin{array}{l}\text { 2. Need to take oral rehydration solution (ORS) to prevent } \\
\text { dehydration }\end{array}$ & $19(38 \%)$ & $31(62 \%)$ \\
\hline 3. Eat small, light meals and avoid fatty or spicy foods & $43(86 \%)$ & $7(14 \%)$ \\
\hline \multicolumn{3}{|l|}{ G. Prevention } \\
\hline $\begin{array}{l}\text { 1. Having very good self-hygiene by always make it as a } \\
\text { habit to wash hands before and after doing something. }\end{array}$ & $21(42 \%)$ & $29(58 \%)$ \\
\hline 2. Avoid eating food from street vendors & $17(34 \%)$ & $33(66 \%)$ \\
\hline
\end{tabular}

Table 3 Application of hygienic lifestyle

\begin{tabular}{llc}
\hline Questions & Yes (\%) & No (\%) \\
\hline $\begin{array}{l}\text { 1. Always wash hands with soap before and after eating } \\
\text { 2. Always wash hands with soap after using the toilet }\end{array}$ & $11(22 \%)$ & $78 \%)$ \\
3. Always wash hand with soap after touching pet/animal or & $16(32 \%)$ & $68 \%)$ \\
$\quad$ come in contact with their waste & $22(44 \%)$ & $56 \%)$ \\
4. Will always wash all fruits or vegetables before eating them & $29(58 \%)$ & $42 \%)$ \\
5. Consuming unpasteurized milk & $29(58 \%)$ & $42 \%)$ \\
6. Drinking untreated tap water & $32(64 \%)$ & $18(36 \%)$ \\
\hline
\end{tabular}

\section{Description of application of hygienic lifestyle}

There were only 6 questions given for the demands of hygienic lifestyle. Based on table 3, only $22 \%$ of them always wash hand with soap before and after eating. There were $68 \%$ of them were not still wash hands with soap after using the toilet. But, $44 \%$ of them agreed to wash hand with soap after touching a pet or animal or when they come in contact with their waste. Most of them which are 58\% said that they will always wash all fruits or vegetables before eating them. In addition, 58\% of them said yes for consuming unpasteurized milk while on the other hand, $64 \%$ of them say yes for drinking untreated tap water.

\section{The knowledge in diarrhea and application of hygienic lifestyle}

$25 \%$ of 8 years old students and also $56 \%$ of the 9 one obtained good score in the knowledge in diarrhea while $88 \%$ from 8 -year-old students and even $44 \%$ of 9 years old student failed to score in knowledge in diarrhea. In total, $34 \%$ of students managed to get a good score for knowledge in diarrhea while $66 \%$ of students failed to do so. On the other hand, $12 \%$ of students from 8 years old managed to get the 
Table 4 Bivariat analysis of the data

\begin{tabular}{|c|c|c|c|c|c|c|}
\hline \multirow[b]{3}{*}{ Variable } & \multicolumn{4}{|c|}{ Knowledge in Diarrhea } & & \\
\hline & \multicolumn{2}{|c|}{ Good } & \multicolumn{2}{|c|}{ Bad } & \multicolumn{2}{|c|}{ Total } \\
\hline & $\mathbf{N}$ & $\%$ & $\mathbf{N}$ & $\%$ & $\mathbf{N}$ & $\%$ \\
\hline \multicolumn{7}{|c|}{ Age of students } \\
\hline 8 years & 3 & $12 \%$ & 22 & $88 \%$ & 25 & 100 \\
\hline \multirow[t]{3}{*}{9 years } & 14 & $56 \%$ & 11 & $44 \%$ & 25 & 100 \\
\hline & \multicolumn{4}{|c|}{ Application of Hygienic Lifestyle } & & \\
\hline & \multicolumn{2}{|c|}{ Good } & \multicolumn{2}{|c|}{ Bad } & \multicolumn{2}{|c|}{ Total } \\
\hline Variable & $\mathbf{N}$ & $\%$ & $\mathbf{N}$ & $\%$ & $\mathbf{N}$ & $\%$ \\
\hline \multicolumn{7}{|c|}{ Age of students } \\
\hline 8 years & 3 & $12 \%$ & 22 & $88 \%$ & 25 & 100 \\
\hline 9 years & 9 & $36 \%$ & 16 & $64 \%$ & 25 & 100 \\
\hline
\end{tabular}

good score in the application of hygienic lifestyle while $36 \%$ from the 9 -year-old student managed to get excellent rating in the application of hygienic lifestyle. Only $88 \%$ from 8 years old student failed to get a good score in the application of hygienic lifestyle while $64 \%$ from 9 years old student failed as well to get a proper score in the same one. Overall, there were $24 \%$ of students who managed to score well while $76 \%$ of the students failed to get a good score in use of hygienic lifestyle.

\section{DISCUSSION}

\section{Distribution of total score}

All the students in both age group of 8 years old and 9 years old were given the same set of questionnaire which consists of 14 questions based on knowledge in diarrhea and also six questions based on the application of hygienic lifestyle. The result of data collected from the sample shows that the students from 9 years old have answered better and scored more compared to the students from the 8 years old group. Total of 600 points was collected by the 9 years old student compare to 436 points obtained by the 8 year old student. It shows that the student of 9 years old have a better understanding of knowledge in diarrhea and also in the application of hygienic lifestyle.

\section{Frequency Distribution of knowledge in diarrhea and personal hygiene}

Having good knowledge of diarrhea and also an excellent personal hygiene among children is an essential way to prevent diarrhea among children. Based on the study conducted among students below 10 years old in SD Santo Yoseph 2, only 17 students which are 34\% managed to have a good score in the knowledge in diarrhea, which shows that majority of the 33 students which is $66 \%$ have poor knowledge in diarrhea. When it comes to the application of hygienic lifestyle, $76 \%$ of the students failed to get a good score while only $24 \%$ of the students managed to score well in this part. Understanding this disease at an early age is essential because there was a study done in Sumba Baya Darat shows that the prevalence of diarrhea was second highest for the age range of 5-14 years old. ${ }^{2}$

\section{Description of the level of knowledge in diarrhea}

According to the study, students get an excellent score in the definition, etiology, which is an excellent understanding of diarrhea. Students are still not aware of the risk factors of diarrhea especially $52 \%$ of them didn't know that contaminated water which can cause diarrhea, $54 \%$ of students disagree that food which is prepared and stored in unhygienic condition causes diarrhea, and finally $52 \%$ of them does not know it's a risk when there is a shortage of adequate sanitation and hygiene. There was a study conducted in Malaysia shows that sanitation had a more significant impact on mortality among children of an illiterate mother. $84 \%$ of students answered correctly for both sign and symptoms questions which says that person with diarrhea experience watery or loose stools, and also during diarrhea will have abdominal cramps. ${ }^{3}$ Even though for the sign and symptoms most of them answered correctly for the 2 questions out of 3, 52\% of students still don't think that they will have fever if diarrhea persists more than one day. Besides that, $90 \%$ of them did not know that diarrhea causes dehydration due to loss of a large amount of water and salt. $74 \%$ of students know that they should drink plenty of water to avoid dehydration and $86 \%$ of them said yes to eat small, light meals and avoid fatty or spicy foods. $62 \%$ of students don't know about taking oral rehydration solution when they 
have diarrhea, and this may be due to their lack of knowledge about dehydration itself. Students have a very bad understanding about prevention because $58 \%$ of students didn't know that having a very good self-hygiene by always make it as a habit to wash hands before and after doing something can prevent diarrhea, and also $58 \%$ of them say no to void eating food from street vendors. A study made in developing countries suggests that a great health impact may be achieved if the hand washing attitude is maintained. ${ }^{4}$

\section{Description of application of hygienic lifestyle}

Application of hygienic lifestyle is also tested among the students to understand more about their attitude towards a healthy lifestyle. Only $22 \%$ of the students always wash hands with soap before and after eating. $68 \%$ of the students are not always wash their hands with soap after using the toilet which is a very poor hygienic. ${ }^{5}$ A study was done in Kota Manado proves that there is a correlation between the attitude of washing hands with soap and the incidence of diarrhea and it clearly correlates with this study. ${ }^{2}$ Majority $56 \%$ of them were not always wash hand with soap after touching pet/animal or come in contact with their waste. 58\% of them always wash all fruits or vegetables before eating them and also still not aware of consuming unpasteurized milk is unhygienic. There were $64 \%$ of them are still drinking untreated tap water. ${ }^{6}$

\section{The knowledge in diarrhea and application of hygienic lifestyle}

Even though students from both 8 years old and nine years old scored poorly in both section which is knowledge in diarrhea and also the application of hygienic lifestyle, the students from 9 years old had scored slightly better than the students of 8 years old. This might be due to their level of maturity and also the experience they had in their lifetime. ${ }^{7}$ There was a study of health education related to diarrhea, personal hygiene, and environmental hygiene among local school children in Navi Mumbai conducted. ${ }^{8,9}$ In this study, a child to child programme was held about knowledge and personal health about diarrhea, and it seems that at the end of the schedule, the students have a better understanding about diarrhea and also personal health. Therefore, this study correlates with the review that has been conducted where the students have a better understanding about diarrhea and also personal hygiene.

\section{CONCLUSION}

According to my aim which has been mentioned earlier, I managed to collect the information about the level of knowledge in diarrhea and also personal hygiene among students below ten years old in SD Santo Yoseph 2, Denpasar. Though the overall knowledge in diarrhea and even personal health among the students are poor, as for how it has been stated in the hypothesis, few students really managed to get a good score which shows that particular students have a better understanding about diarrhea and personal hygiene compared to rest of the students.

\section{REFERENCES}

1. Rajan Inderan, S., Weta, W. Correlation between clean and healthy lifestyle behavior of mother with the incident of diarrhea in toddlers at working area of Puskesmas I Negara, Jembrana - Bali. Intisari Sains Medis 2018; 9(3). DOI:10.15562/ism.v9i3.180

2. Handita, C., \& Sungkar, S. The Trend of Diarrhea in Kodi and Kodi Utara subdistricts, Sumba Barat Daya District in 2013 and Its Related Factors; 2013.

3. Djrkoni, I.H., Lampus, B.S., Siagian, L.E., Kaunang, W.P.J., Palandeng, H. Hubungan Perilaku Cuci Tangan Pakai Sabun Dengan Kejadian Diare di SD Advent Sario Kota Manado; 2014.

4. Huttly, S.R.A., Morris, S.S., Pisani, V. Prevention of diarrhea in young children in developing countries; 1997: 75(2).

5. Wulandari PDA, Wirata G, Putri CWS. Hubungan Antara Asupan Energi, Asupan Protein Dan Aktivitas Fisik Terhadap Status Gizi Penduduk Lanjut Usia Di Wilayah Kerja Upt Kesmas Blahbatuh II, Kecamatan Blahbatuh, Kabupaten Gianyar. E-Jurnal Medika Udayana, 2015; 4(7).

6. Grandinata Soeseno, W., Bikin Suryawan, I., Suarca, K. Hubungan antara derajat dehidrasi dengan penurunan berat badan pada anak diare usia 1 sampai 5 tahun di ruangan kaswari dan poliklinik anak RSUD Wangaya kota Denpasar. Intisari Sains Medis 2019; 10 (1). DOI:10.15562/ ism.v10i1.322

7. Joewono M, Karmaya INM, Wirata G, Yuliana, Widianti IGA, Wardana ING. Drawing method can improve musculoskeletal anatomy comprehension in medical faculty student. Anatomy and Cell Biology. 2018;51(1):14-18. DOI: https://doi.org/10.5115/acb.2018.51.1.14

8. Jadhav, S.R., Patankar, R.M., Pandit, D. An Interventional Study of Health Education Related to Diarrhea, Personal Hygiene, and Environmental Hygiene among Municipal School Children in Navi Mumbai; 2015.

9. Nyorong, M., \& Burhan,H. Influence of an Inquiry-Based Learning Model on Maternal Behavior in Response to Diarrhea in Children under the Age of Five Years at the Tempe Health Center, Wajo Regency, Indonesia; 2015.

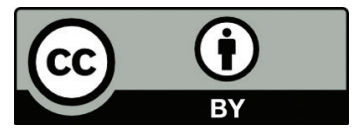

This work is licensed under a Creative Commons Attribution 